\title{
Áhrif tónlistar í auglýsingum á vörumerkjavirði
}

\author{
Friðrik Eysteinsson, Kári Kristinsson og Katrín Halldórsdóttir ${ }^{1}$
}

\begin{abstract}
Ágrip
Framkvæmd var tilraun, með pað að markmiði að kanna áhrif tónlistar í auglýsingum á vörumerkjavirði. Útvarpsauglýsing fyrir ópekkt vörumerki (orkudrykk sem er ekki á markaðnum á Íslandi) var útfærð á prennan hátt. Undir tal auglýsingarinnar, sem var eins í öllum premur tilvikum, var annars vegar sett frumsamið lag sem samsvaraði vörumerkinu, hins vegar lag sem samsvaraði pví ekki og í priðja tilfellinu var engin tónlist. Sama lag, en í mismunandi útsetningum, var notað í báðum tilraunahópum. Pvert á niðurstöður fyrri rannsókna benda niðurstöðurnar ekki til pess að aukin skynjuð samsvörun milli tónlistar og vörumerkis auki vörumerkjavirði.
\end{abstract}

\begin{abstract}
An experiment, which had the aim of finding out what effect music in advertising has on brand equity, was conducted. A radio advert for an unknown brand (an energy drink not on the Icelandic market) was prepared and had three different versions. These featured the same voice component of the advert accompanied by music that fit with the image of the brand, music that did not fit the brand's image and no music. The same originally scored song was used in both the experimental groups but with different arrangements. In contrast to previous research our results do not indicate that increased congruency between musical genre and the brand increases brand equity.
\end{abstract}

JEL flokkun: M31, M37

Lykilhugtök: Vörumerkjavirði, Auglýsingar

\footnotetext{
${ }^{1}$ Friðrik Eysteinsson er aðjunkt við Viðskiptafræðideild Háskóla Íslands, Kári Kristinsson er lektor við Viðskiptafræðideild Háskóla Íslands og Katrín Halldórsdóttir er MS í markaðsfræði og alpjóðaviðskiptum frá Viðskiptafræðideild Háskóla Íslands. Höfundar pakka tveimur ónafngreindum ritrýnum og pátttakendum í rannsóknamálstofu Viðskiptafræðistofnunar fyrir gagnlegar ábendingar. 


\section{Inngangur}

Tónlist í auglýsingum hefur fengið aukna athygli rannsakenda síðustu ár enda er hún talin vera einn mikilvægasti hluti skapandi uppistöðu margra auglýsinga (Kellaris, Cox og Cox, 1993). Рað er pví mikilvægt að stjórnendur hafi góða yfirsýn yfir pau áhrif sem mismunandi tónlistartegundir í auglýsingum (t.d. rokk, jass eða klassísk tónlist) geta haft á neytendur. Með pví að auka við pekkinguna á pví hvaða ávinningi má fá fram með mismunandi útfærslum tónlistarinnar eiga auglýsendur auðveldara með að meta og gera greinarmun á mismunandi valkostum og eru pess vegna betur í stakk búnir til að taka bestu ákvörðunina hverju sinni (Oakes, 2007).

Niðurstöður rannsókna á áhrifum tónlistar í auglýsingum hafa í gegnum tíðina verið mótsagnakenndar og hefur petta gert rannsakendum erfiðara fyrir að draga ályktanir út frá peim (Oakes, 2007). Petta er líklega sökum pess hvers eðlis rannsóknarefnið er og hve erfitt er að halda viðeigandi breytum stöðugum til að hægt sé að fá út áreiðanlegar niðurstöður.

Viðfangsefnið tónlist í auglýsingum er flókið. Líklegt er að flytjendur laga og vinsældir peirra eða peirrar tónlistar sem er notuð, tilfinningar og minningar tengdar lögum eða flytjendum og svo mætti lengi telja, hafi áhrif í rannsóknum og geti skilað sér í mótsagnakenndum niðurstöðum. Einnig getur fyrri reynsla af peim vörumerkjum sem notuð eru í rannsóknum haft áhrif á niðurstöður peirra (Keller, 1993). Einnig ber að hafa í huga að margar pessara rannsókna notast við pátttöku nemenda í tilraunaaðstæðum par sem peim er sagt að einbeita sér að áreitinu sem er fyrir hendi. Раð er viðurkennt að við raunverulegri aðstæður virka auglýsingar á hlutlausari (passive) hátt á hlustandann (Oakes, 2007).

Í rannsóknum á pessu viðfangsefni hefur oftar en ekki verið notuð tónlist sem ekki er sérstaklega samin í pessum tilgangi og pví oft ekki um sömu tónsmíð/laglínu að ræða milli tilraunahópa (Simpkins og Smith, 1974; Kellaris og Cox, 1989; MacInnis og Park, 1991; Kellaris o.fl., 1993; Hung, 2000 \& 2001; North, Shilcock og Hargreaves, 2003; Wilson, 2003; North o.fl., 2004; Allan, 2006). Undantekningin er pegar einungis tónblæ eða takti tónlistarinnar er hagrætt (Oakes og North, 2006) en pá er ekki um samanburð á tónlistartegundum sem slíkum að ræða heldur einungis taktmun sama lags í sama búningi. Раð er pví áhugavert að einangra breytuna tónlistartegund eins og unnt er og kanna áhrif hennar sem slíkrar á vörumerkjavirði (brand equity).

Prjár auglýsingar voru búnar til fyrir vörumerkið Blue Storm. Saminn var lagbútur sem var útfærður á tvenns konar hátt, í rólegri útgáfu og dansútgáfu. Til samanburðar var ein auglýsing án tónlistar. Frumbreytan í tilrauninni var pví tegund tónlistar. Textinn var eins í öllum premur auglýsingunum og sama upptakan notuð. Hver pátttakandi heyrði umrædda auglýsingu á einu formi. Eftir að pátttakendur höfðu hlustað á útvarpspátt í heild sinni voru peir beðnir um að svara nokkrum spurningum sem viðkomu vörumerkjavitund. Eftir pað var umrædd auglýsing spiluð ein og sér aftur og pátttakendur spurðir út í vörumerkið, tónlistarsmekk og fleira. Fylgibreytur tilraunarinnar voru mæling á vitund og ímynd vörumerkisins.

Eftir pví sem best er vitað hefur ekki verið gerð tilraun áður par sem frumsamin tónsmíð er notuð og tvær ólíkar útsetningar á henni gerðar til pess annars vegar að búa til útgáfu sem hæfir vörumerkinu og hins vegar útgáfu sem hæfir vörumerkinu ekki en slíkt útilokar möguleika á fyrri reynslu af tónlistinni sem gæti skekkt niðurstöður. 


\section{Vörumerkjastjórnun}

Virði vörumerkis er samsett úr virði vörunnar sjálfrar og pví virði sem skapast vegna hugrenningatengsla við vörumerkið sem slíkt (Keller, Apéria og Georgson, 2008). Í hugum neytenda endurspeglar pað alla pá upplifun eða reynslu sem peir hafa haft af tiltekinni vöru. Vörumerki einfalda val fyrir neytendum, gefa loforð um ákveðin gæði, draga úr áhættu og skapa traust (Keller og Lehmann, 2006). En vörumerki eru einnig verðmæt fyrir framleiðendur. Vörumerki auðkenna og aðgreina vörur framleiðenda og geta haft áhrif á atferli neytenda (Keller o.fl., 2008).

Vörumerkjastjórnun gengur út á að fá hugmyndir að markaðsaðgerðum og hrinda peim í framkvæmd til pess að byggja upp og viðhalda vörumerkjavirði (t.d. Keller, 1993 og Yoo, Donthu og Lee, 2000). Hér á eftir verður farið nánar í hugtakið viðskiptavinagrundað vörumerkjavirði (consumer-based brand equity) og hvernig slíkt virði er byggt upp. Pví næst er fjallað um hugtökin vörumerkjavitund (brand awareness) og vörumerkjaímynd (brand image).

\subsection{Viðskiptavinagrundað vörumerkjavirði}

Vörumerkjavirði er pað viðbótarvirði sem vörumerki ljær vöru (Farquhar, 1989). Samkvæmt Aaker (1991) er vörumerkjavirði margvítt hugtak sem tengist pví að vörumerki auka við eða draga úr virði vöru. Pær víddir vörumerkjavirðisins sem snúast um skynjun neytenda eru vörumerkjavitund, hugrenningatengsl við vörumerki (brand associations) og skynjuð gæði (perceived quality) (Aaker, 1991).

Keller (1993) skilgreinir viðskiptavinagrundað vörumerkjavirði sem pann mun á áhrifum sem pekking á vörumerki hefur á viðbrögð neytenda við markaðsfærslu pess vörumerkis. Vörumerki eru sögð búa yfir jákvæðu viðskiptavinagrunduðu vörumerkjavirði pegar neytendur bregðast á betri hátt við vöru og markaðsfærslu hennar pegar vörumerkið er pekkt en pegar pað er ópekkt. Víddir viðskiptavinagrundaðs vörumerkjavirðis eru samkvæmt Keller (1993) vörumerkjavitund og vörumerkjaímynd (Keller, 1993) en hún innifelur skynjuð gæði Aakers (1991) og hugrenningatengsl við vörumerki.

Segja má að Farquhar (1989), Aaker (1991) og Keller (1993) skilgreini vörumerkjavirði á svipaðan hátt, p.e. sem pað viðbætta virði sem vörumerki ljær vöru. Víddir vörumerkjavirðis Kellers (1993) og pær víddir Aakers (1991) sem snúa að skynjun neytenda eru líka í raun pær sömu.

Eins og fyrr segir gengur vörumerkjastjórnun út á pað að fá hugmyndir að og hrinda í framkvæmd markaðsaðgerðum sem hafa pað аð markmiði að byggja upp og viðhalda vörumerkjavirði. Раð er gert með pví að byggja upp vörumerkjavitund og mynda hugrenningatengsl við vörumerkið (ímynd) sem eru jákvæð, sterk og einstök. Hægt er að ná pessu fram með pví m.a. að velja viðeigandi vörumerkjaauðkenni (brand elements) (Keller, 1993) og með markaðssamskiptum (marketing communications) (Keller, 1993; Yoo o.fl., 2000).

Pegar talað er um vörumerkjaauðkenni er átt við vörumerkjaheiti og vefslóð, myndmerki (logo) og tákn (symbol), fígúrur (characters), slagorð (slogans), auglýsingastef (jingles) og pakkningar (packaging) (Keller, 1993). Auðkenni eru notuð til að aðgreina og við val á peim parf m.a. að hafa í huga að pau séu minnisstæð (memorable), hafi merkingu (meaningful) og séu viðkunnanleg (likeable) (Keller o.fl., 2008).

Í fyrsta lagi ætti að vera lagt upp með að auðkennin séu minnisstæð, p.e. að pau auðveldi neytendum að rifja upp (recall) eða bera kennsl á vörumerkið (recognize) (Keller, 1993). Til að mynda getur pað verið ruglandi fyrir neytandann og hindrað upprifjun ef notuð 
eru mismunandi auglýsingastef fyrir sama vörumerki . Ef pað er erfitt að muna eftir heiti vörumerkisins, eða erfitt að leggja auglýsingastef pess á minnið, pá dregur pað að sjálfsögðu úr vörumerkjavitund.

Í annan stað purfa auðkenni að hafa merkingu. Pau geta sagt til um hvaða vöruflokki varan tilheyrir. Í sumum tilfellum geta auðkennin tengst vöruflokknum. Petta aðstoðar við minnisgeymd, auðveldar tengingar og eykur líkurnar á að vörumerkið komi upp í hugann við kaup- eða neyslutilefni (Keller, 1993). Sem dæmi má nefna að ef auglýsingastef tengist vörumerkinu og hefur merkingu pá minnir pað meira á vörumerkið og ýtir par með undir upprifjun.

Að lokum er mikilvægt að auðkennin séu viðkunnanleg, p.e. að neytendum og mögulegum neytendum líki vel við pau (Keller o.fl., 2008).

Með markaðssamskiptum er hægt að kynna vörumerkið fyrir neytendum og skerpa á eða búa til hugrenningatengsl sem auka virði pess (sjá t.d. Keller, 1993 og Yoo o.fl., 2000). раð er til dæmis hægt að gera með auglýsingum í ljósvakamiðlum en undir tali peirra er oftast leikin tónlist.

\subsection{Vörumerkjavitund}

Vörumerkjavitund felur í sér tvennt: Annars vegar að neytendur geti borið kennsl á vörumerki sem peir hafa áður verið kynntir fyrir (brand recognition), sem sagt að ef tiltekið vörumerki er gefið sem vísbending pá geti peir með réttu sagt að peir hafi heyrt eða séð vörumerkið áður; og hins vegar að peir geti rifjað upp vörumerkjaheitið pegar peir heyra minnst á vöruflokk pess (brand recall) (Keller, 1993).

\subsection{Vörumerkjaímynd}

Vörumerkjaímynd hefur verið skilgreind sem skynjun neytenda á vörumerki og endurspeglast af peim hugrenningatengslum sem neytandinn geymir í minninu (Keller, 1993). Hér skiptir máli hversu jákvæðar, sterkar og einstakar vörumerkjatengingarnar eru í hugum neytenda. Árangur markaðsaðgerða endurspeglast í myndun jákvæðra vörumerkjatenginga, sem sagt að neytendur trúi pví að vörumerkið búi yfir peim eiginleikum sem peir sækjast eftir pannig að jákvætt viðhorf til vörumerkisins myndist. Hve sterkar tengingarnar eru við vörumerkið er háð pví hvernig upplýsingum er umbreytt og pær geymdar í minni neytenda. Styrkleiki tenginganna veltur bæði á pví hve mikla vinnslu upplýsingarnar fá sem og gæðum pessarar vinnslu. Pví dýpra sem neytandi hugsar um upplýsingarnar og tengir pær við vörumerkið peim mun sterkari verða tengingarnar. En ekki er nóg að vörumerkjatengingarnar séu jákvæðar og sterkar, pær purfa einnig að vera einstakar, p.e. að geta aðgreint eitt vörumerki frá öðru í hugum neytenda og pannig haft áhrif á val peirra (Keller, 1993).

\section{Tónlist í auglýsingum}

Tónlist í auglýsingum hefur fengið aukna athygli rannsakenda síðustu ár enda er tónlist gríðarlega mikilvægur hluti auglýsinga (Kellaris o.fl., 1993). Áhrif tónlistar í auglýsingum hafa til dæmis verið rannsökuð með tilliti til klassískrar skilyrðingar (classical conditioning) (Gorn, 1982), hlutverks aðildar (involvement) (MacInnis og Park, 1991) og nýlega hefur áhugi aukist á hlutverki skynjaðrar samsvörunar (perceived congruency) milli tónlistar og vörumerkis (North, Hargreaves, MacKenzie og Law, 2004; Oakes, 2007). 


\subsection{Klassísk skilyrðing}

Klassísk skilyrðing hefur verið notuð til að útskýra mikilvægi tónlistar og má par nefna til sögunnar rannsókn Gorn (1982). Gorn paraði vinsæla og óvinsæla tónlist saman við myndir af pennum. Pennarnir í tilrauninni voru ýmist bláir eða brúnir. Pátttakendum var boðið að velja sér penna eftir pátttökuna í tilrauninni og kom pá í ljós að í meirihluta tilfella völdu pátttakendur frekar pennana sem höfðu verið paraðir við vinsælu tónlistina. Prátt fyrir áhugaverðar niðurstöður pessarar rannsóknar hefur kenningin um klassíska skilyrðingu verið gagnrýnd og sögð ófullnægjandi skýring á mikilvægi tónlistar í auglýsingum. Gagnrýnin hefur aðallega tengst peirri umræðu að mögulega gætu niðurstöður verið vegna póknunaráhrifa (demand characteristics) en einnig hefur hún beinst að pví að erfitt er að styðja hugmyndirnar með reynsluprófun (empirically) (North, o.fl., 2004).

\subsection{Hlutverk aðildar}

Hlutverk aðildar í tilraunum tengdum auglýsingum hefur einnig fengið töluverða athygli í útskýringum á mikilvægi tónlistar í auglýsingum, sérstaklega í kjölfar nálgunar klassískrar skilyrðingar (Gorn, 1982; North o.fl., 2004). Pegar talað er um aðild er vísað til pess að hve miklu leyti pátttakendur eru meðvitaðir um pað að peim beri að fylgjast með auglýsingunni í tilrauninni. Pátttakendur veita auglýsingunni ýmist mikla athygli eða litla. Annað hvort hafa peir tækifæri, hvatningu eða getu til pess að fylgjast með upplýsingum sem koma fram í auglýsingunni (háir í aðild) eða ekki (lágir í aðild) (North, o.fl., 2004).

Mikilvægi aðildar má til að mynda sjá í framhaldstilraun Gorn (1982). Helmingi pátttakenda í pennatilrauninni var ekki sagt frá pví í upphafi tilraunarinnar að peir fengju að velja sér penna í lok rannsóknarinnar en hinn helmingur pátttakendanna fékk hins vegar að vita pað fyrir fram. Peir sem vissu ekki að peir fengju að velja sér penna voru líklegri til að velja penna sem paraður hafði verið við vinsælu tónlistina. Peir sem hins vegar höfðu fengið að vita fyrir fram að peir fengju að velja sér penna völdu sér penna frekar eftir lýsingu á pennanum (upplýsingum pess efnis að penninn væri ekki kámugur). Peir sem vissu að peir fengju penna að launum veittu innihaldi auglýsingarinnar meiri athygli. Peir voru pví hærri í aðild. Samkvæmt pessari tilraun pykir pví líklegra að samsvörun milli tónlistar og auglýsingar hafi meiri áhrif á pá sem eru lágir í aðild en pá sem eru háir (North, o.fl., 2004).

\subsection{Samsvörun milli tónlistar og vörumerkis}

Í fræðunum er fjallað til jafns um hugtökin musical fit og musical congruency en hér verður notað íslenska hugtakið samsvörun (congruency) og lagður sami skilningur í hugtakið og hjá MacInnis og Park (1991). Samkvæmt peim vísar hugtakið til pess að hve miklu leyti neytendur skynja að tónlistin sé viðeigandi fyrir pað samhengi sem hún er í, p.e. hversu vel tónlistin hæfir vörumerkinu. Tíu mismunandi skilgreiningar á samsvörun hafa verið settar fram (Oakes, 2007). Hér er athyglinni beint að samsvöruninni milli tegundar tónlistar (musical genre) og vörumerkjavirðis.

Í peirri tilraun sem hér verður til umfjöllunar er varan orkudrykkur en markhópurinn er ungt fólk. Algengt er að sá aldurshópur noti orkudrykki í bland við áfengi og eru orkudrykkir pví gjarnan tengdir við skemmtanalíf ungs fólks. Í nýlegri rannsókn kom í ljós að um $40 \%$ neytenda orkudrykkja nota slíka drykki fyrst og fremst í pessum tilgangi. Markaðssetning orkudrykkja hefur pví hingað til aðallega beinst að ungu fólki og gjarnan með tilvísun í skemmtanalífið (Attila og Cakir, 2010). Með petta í huga kemur ekki á óvart að hraður taktur og almennt stuð einkenni tónlist í orkudrykkjaauglýsingum. Petta er ástæða 
pess að í peirri tilraun sem hér verður til umfjöllunar er gert ráð fyrir pví að pátttakendur skynji aukna samsvörun milli tónlistarinnar og vörumerkisins pegar danstónlist hljómar í bakgrunni en upplifi aftur á móti ekki samsvörun pegar peir heyra orkudrykkjaauglýsingu með rólega eða jafnvel enga tónlist í bakgrunni.

\section{4 Áhrif tegundar tónlistar í auglýsingum á vörumerkjavitund}

Áhrif tegundar tónlistar í auglýsingum á vörumerkjavitund hafa lítið verið rannsökuð hingað til. Tom (1990) bar saman áhrif pess að nota annars vegar pekkt lög (chart hits) í auglýsingum og hins vegar lög sem sérstaklega höfðu verið samin með tilliti til pess að pau hæfðu vörumerkinu. Niðurstaða hennar var sú að síðarnefndu lögin hefðu meiri áhrif á upprifjun á vörumerkjaheiti (brand recall).

Yalch (1991) komst að peirri niðurstöðu að vörumerkjaupprifjun væri betri pegar auglýsingastef (jingles) sem sérstaklega eru samin fyrir vörumerki voru notuð en pegar pau voru ekki notuð. Petta átti hins vegar einungis við pegar vitundin snerist um að muna eftir vörumerki en ekki pegar hún snerist um að kannast við pað.

Að síðustu komust North o. fl. (2004) að peirri niðurstöðu að hlustendur myndu betur eftir vörumerkinu sem verið var að auglýsa væri samsvörunin milli tegundar tónlistar og vörumerkis til staðar. Í rannsókn North o.fl. var ekki notuð frumsamin tónlist.

Með hliðsjón af pessum rannsóknum setjum við pví fram pá tilgátu að aukin skynjuð samsvörun auki vörumerkjavitund.

Tilgáta 1: Aukin skynjuð samsvörun milli tegundar tónlistar og vörumerkis hefur jákvæð áhrif á vörumerkjavitund.

\subsection{1 Áhrif tegundar tónlistar í auglýsingum á vörumerkjaímynd}

Hung (2000) komst að pví að samsvörun milli tegundar tónlistar og peirrar vöru sem verið er að auglýsa hefur jákvæða áhrif á ímynd vörumerkis vörunnar. Til að mynda var ímynd vörunnar (brasilískt kaffi) jákvæðust pegar brasilísk tónlist hljómaði í bakgrunni auglýsingarinnar. Í rannsókn Hung (2001) kom einnig í ljós að samsvörun milli tónlistartegundar og vörumerkisins getur leitt til jákvæðara viðhorfs til pess. Í peirri rannsókn setti hann tvenns konar tegund tónlistar, klassíska tónlist (Vivaldi) og rokk, (Garbage) undir tal sömu auglýsingarinnar og komst að peirri niðurstöðu að í peim tilfellum sem klassíska tónlistin var notuð varð ímynd hlustenda jákvæðari í garð vörumerkisins. Í pessu tilfelli var vörumerkið verslunarmiðstöð í dýrari kantinum (up-market) og fyrir fram var búist við meiri samsvörun með klassísku tónlistinni en rokktónlistinni.

Að síðustu benda niðurstöður rannsókna North o.fl. (2004) og Lavack, Thakor og Bottausci (2008) til pess að pví meiri sem samsvörunin er milli tónlistartegundar og vörumerkis peim mun betri verði skynjuð ímynd pess. Í tilraunum peirra voru ekki notuð frumsamin lög.

Með hliðsjón af pessum rannsóknum setjum við pví fram pá tilgátu að aukin skynjuð samsvörun hafi jákvæð áhrif á vörumerkjaímynd.

Tilgáta 2: Aukin skynjuð samsvörun milli tegundar tónlistar og vörumerkis hefur jákvæð áhrif á vörumerkjaímynd. 
Hafa ber í huga að pótt pekkt lög hafi pann eiginleika að geta vakið athygli fólks pá geta pau í leiðinni verið tilfinningahlaðin og kallað fram jákvæðar eða neikvæðar minningar.

Að líka vel við tónlist (musical liking) í auglýsingu gerir pað аð verkum að hlustendur hafa jákvæðari tilfinningar í garð vörumerkisins. Pegar fólki líkar ekki vel við tónlist í auglýsingu getur pað leitt til pess að skynjuð ímynd vörumerkis verði verri. Petta kom til að mynda í ljós í rannsókn par sem tegund tónlistar sem nýtur minni almennra vinsælda, kántrítónlist, var borin saman við tegund tónlistar sem nýtur meiri almennra vinsælda, rokktónlist. Par kom í ljós að pegar kántrítónlist var notuð í auglýsingu var vörumerkið skynjað með verri ímynd en pegar rokk var notað eða engin tónlist (Simpkins og Smith, 1974). Eins og fyrr segir má ef til vill rekja pessi áhrif til samsvörunar. Fólk gerir sér grein fyrir pví að auglýsendur leitast við að mynda jákvæðar tengingar við vörumerki sitt. Pess vegna getur pað orðið vart við ósamsvörun pegar vörumerki er parað við tónlist sem ekki nýtur almennra vinsælda (Oakes, 2007).

Út frá pessum rannsóknum má álykta að sú tónlist sem hlustendur kunna vel að meta hafi jákvæðari tengsl við ímynd vörumerkis en tónlist sem hlustendur kunna síður að meta.

Tilgáta 3: Að líka vel við pá tegund tónlistar sem hljómar í auglýsingu hefur jákvæð tengsl við skynjaða ímynd vörumerkis.

\section{Aðferð}

Í pessum kafla verður fjallað um rannsóknarsniðið sem notað var, pátttakendur í tilrauninni, áreitið, mælitækið og framkvæmd.

\subsection{Rannsóknarsnið}

Viðfangsefnið tónlist í auglýsingum er flókið eins og áður hefur komið fram. Ef rannsóknarsnið er ekki vandað er líklegt að samsláttur (confounding factor) komi til með að lita rannsóknina. Рað er pví mikilvægt að reyna að einangra utanaðkomandi pætti pegar samsvörun milli tónlistar og vörumerkis og áhrif samsvörunnar og tónlistarsmekks á vörumerkjavirði eru skoðuð.

Markmiðið með pessari tilraun er meðal annars að kanna hvort tónlistin ein og sér, án nokkurs texta eða forsögu, hafi áhrif á vörumerkjavitund og ímynd á pann hátt sem samsvörunarkenningin segir til um. Kellaris o.fl. (1993) lögðu vissulega áherslu á að velja lög sem fólk kannaðist almennt lítið við en til að útiloka alla möguleika á fyrri reynslu af tónlistinni og til að tryggja að sem minnstur mögulegur munur milli tónlistar í tilraunahópunum tveimur sé til staðar er mikilvægt að nota frumsamda tónlist og nota sömu laglínu í báđum hópum. Pó er einstaka breytum hagrætt til að nálgast tónsmíð sem annars vegar samsvarar ekki vörumerkinu og hins vegar tónsmíð sem samsvarar pví.

Að mati höfunda og tónlistarmanns sem höfundar voru í samstarfi við var ekki hægt að hagræða einungis taktinum og halda öllu öðru óbreyttu án pess að pað kæmi niður á annarri hvorri tónsmíðinni (dægurlaginu eða danslaginu). Раð myndi pví draga úr trúverðugleika laganna. Pegar verið er að semja lag sem á að tilheyra tveimur ólíkum tónlistartegundum, eins og í pessari tilraun, purfa báđar útgáfur lagsins að vera smekklegar og trúverðugar til pess að hægt sé að draga ályktanir út frá niðurstöðunum. Pví nægir ekki í pessu tilfelli að hagræða til að mynda einungis takti lagsins.

Eins og fyrr segir eru hlustendur auglýsinga í raunaðstæðum yfirleitt óvirkari (passive) hlustendur en pátttakendur í tilraunum og pví lágir í aðild. Petta er vegna pess að 
pátttakendur í tilraunum gera sér oft grein fyrir pví að peim ber að hlusta vandlega á áreitið sem fyrir hendi er (Oakes, 2007). Pátttakendur pessarar rannsóknar eru ekki taldir háir í auglýsingaaðild par sem peir eru ekki meðvitaðir um hlutverk sitt í pessari tilraun heldur er peim talin trú um að markmiðið sé að kanna viðhorf peirra og skoðun á útvarpspætti sem peir eru látnir hlusta á. Nokkrum auglýsingum er hins vegar laumað inn í útvarpspáttinn og ein peirra er auglýsingin sem tilraun pessi gengur út á. Pessi aðferð færir tilraunaaðstæður nær raunverulegum aðstæðum og ætti að virka betur heldur en að láta pátttakendur hlusta á auglýsingar og vinna síðan prautaverkefni (distraction task) áður en peir svara spurningum tengdum auglýsingunum.

Sama laglínan var notuð í báđum tilraunahópum en útsett á mismunandi vegu til að hægt væri að bera saman ólíkar tónlistartegundir. Reynt var að haga aðstæðum pannig að pær væru sem líkastar raunaðstæðum og auglýsingaaðild pátttakenda lág. Vörumerkið var nýtt og ópekkt á pessum markaði og tryggt var að ef einhver pátttakandi hefði samt sem áður fyrri reynslu af vörumerkinu eða hefði heyrt af pví áður væru svör hans felld út. Enn fremur var stuðst við raunverulega útvarpsauglýsingu fyrir petta tiltekna vörumerki við gerð auglýsingarinnar og var hún pýdd og sniðin að pörf markaðarins.

Eftir pví sem best er vitað hefur ekki verið gerð tilraun með pessu sniði áður par sem ný tónsmíð er notuð og tvær ólíkar útsetningar á henni gerðar til pess að búa bæði til útgáfu sem hæfir vörumerkinu og útgáfu sem hæfir pví ekki. Markmiðið var að styðjast við fyrri rannsóknir á pessu sviði og reyna að ganga skrefinu lengra í stjórnun breyta með pær upplýsingar í huga sem fræðin hafa veitt hingað til.

\subsection{Dátttakendur}

Pátttakendur voru 199 talsins og voru peir fengnir með hentugleikaúrtaki. Úrtakið samanstóð af grunn- og meistaranemum við Viðskiptafræðideild Háskóla Íslands. Skipt var í hópana prjá af handahófi. Pátttakendur í tilrauninni voru á aldrinum 18-58 ára. Dreifing aldurs í úrtakinu var ójöfn, tæplega 75\% pátttakenda voru á aldrinum 20-30 ára. Meðalaldur í úrtakinu var 27 ár.

Dreifing kynjanna í úrtakinu var nokkuð jöfn, um 57\% konur og 43\% karlar. Kynjaskipting milli hópanna priggja var hins vegar frekar ójöfn. Munur á kynjaskiptingunni milli hópa var pó ekki marktækur. Fjórir einstaklingar sögðu ekki til kyns.

\section{3 Áreiti}

Áreitin í tilrauninni voru prjár auglýsingar fyrir vörumerkið Blue Storm. Auglýsingarnar voru eins að öllu leyti nema einu. Breytan sem var hagrætt var tónlistarbreytan. Tónlist var í tveimur auglýsinganna í ólíkum útfærslum en ein auglýsingin var án tónlistar. Hver tilraunahópur heyrði einungis eina útgáfu af auglýsingunni. Útvarpspátturinn var spilaður í gegnum hljómtæki sem voru til staðar í premur mismunandi kennslustofum og í hverjum útvarpspætti mátti heyra eina útgáfu af orkudrykkjarauglýsingunni. Í öllum tilvikum var upptakan spiluð einu sinni fyrir pátttakendur og pegar peir höfðu svarað fyrri hluta spurninganna var umrædd auglýsing spiluð einu sinni enn fyrir hópinn. Hljóðstillingar voru hafðar eins í stofunum premur.

Nánar um hagræddu breytuna: Lagbútur var saminn og útsettur í tveimur útgáfum, dansútgáfu (sem samsvarar vörumerkinu og auglýsingunni) og rólegri útgáfu (sem samsvarar ekki vörumerkinu og auglýsingunni). Tónsmíðin og útsetningin var í höndum starfandi tónlistarmanns sem leitað var til vegna rannsóknarinnar. Allar prjár auglýsingarnar voru fyrir sama vörumerkið (Blue Storm orkudrykkur) en petta vörumerki er ekki á markaði 
hér á landi. Textinn í auglýsingunum var fenginn að láni úr erlendri útvarpsauglýsingu fyrir petta tiltekna vörumerki og var breytt á nokkrum stöðum til að hæfa betur íslenskum aðstæðum. Útsetningar lagsins voru ólíkar en í báðum tilfellum voru lögin í sömu tóntegund, laglínan leikin á sama hraða og par sem pví var við komið voru notuð sömu hljóðfæri í útfærslunum tveimur.

\subsection{Mælitæki}

Vörumerkjavitund var mæld með tvennum hætti. Annars vegar voru pátttakendur beðnir um að telja upp pau vörumerki sem peir myndu eftir að hefðu verið auglýst á meðan á útvarpspættinum stóð. Hins vegar voru peir beðnir um að haka við vörumerki (5 vörumerki voru talin upp, par af tvö skálduð) sem peir myndu eftir að hefðu verið auglýst í útvarpspættinum.

Pátttakendur voru síðan spurðir, eftir að auglýsingin hafði verið endurtekin, hvernig peim hafi fundist tónlistin samsvara skilaboðunum í auglýsingunni annars vegar og vörunni hins vegar (samsvaraði vörumerkinu). Fullyrðingarnar hljóðuðu pannig, „Tónlistin úr auglýsingunni Blue Storm átti vel við skilaboð auglýsingarinnar“ annars vegar og "Tónlistin úr auglýsingunni Blue Storm átti vel við vöruna" hins vegar. Hægt var að svara spurningunum á 11 punkta Likert kvarða par sem 0 stóð fyrir „„mjög ósammála“ og 10 fyrir „mjög sammála“.

Vörumerkjaímynd var mæld á svipaðan hátt og North o.fl. (2004) gerðu með pví að setja fram ákveðnar fullyrðingar. Tekin voru fimm viðtöl við háskólanema til að fá frekari hugmynd um æskilega ímynd orkudrykkjar til að nálgast pá ímyndarpætti sem efst eru í hugum fólks pegar orkudrykkir eru annars vegar. Að lokum voru valdar sex fullyrðingar sem taldar voru lýsa æskilegum eiginleikum orkudrykkja. Pátttakendur svöruðu á 11 punkta Likert kvarða hversu ósammála/sammála peir voru fullyrðingunum um orkudrykkinn Blue Storm, par sem 0 stóð fyrir „mjög ósammála fullyrðingunni“ og 10 stóð fyrir „mjög sammála fullyrðingunni“.

Einnig voru nokkrar bakgrunnsbreytur og spurningar um tónlistarsmekk. Að lokum var spurt hvort pátttakandi hefði áður heyrt um vörumerkið eða hefði reynslu af pví til að útiloka áhrif fyrri reynslu af vörumerkinu.

\subsection{Framkvæmd}

Pátttakendur hlustuðu á stutt brot (6 mínútur) úr útvarpspætti sem var settur saman fyrir tilraunina. Auglýsingahlé var í útvarpspættinum og hver pátttakandi heyrði par eina útgáfu af umræddri auglýsingu ásamt tveimur öðrum auglýsingum sem voru fengnar að láni frá auglýsingastofu. Petta var blind tilraun í peim skilningi að pátttakendum var talin trú um að peir væru að taka pátt í viðhorfskönnun fyrir umræddan útvarpspátt.

\section{$5 \quad$ Niðurstöður}

Svörum tveggja einstaklinga var eytt úr gagnasafninu vegna pess að peir höfðu fyrri reynslu af vörumerkinu. Svörum eins pátttakanda til viðbótar var hent út sökum pess að hann svaraði aðeins helmingi spurninganna og sagði ekki til um hvort hann hefði fyrri reynslu af vörumerkinu. 
Tafla 1. Teldu upp vörumerkin sem voru auglýst

\begin{tabular}{lcccc}
\hline & \multicolumn{3}{c}{ Áreiti } & \\
\cline { 2 - 4 } & Danstónlist & Engin tónlist & Róleg tónlist & Heild \\
Man ekki eftir vörumerkinu & 58 & 47 & 48 & 153 \\
Man eftir vörumerkinu & 17 & 19 & 10 & 46 \\
\cline { 2 - 4 } & 75 & 66 & 58 & 199 \\
\hline
\end{tabular}

Tafla 2. Hakaðu við pau vörumerki sem voru auglýst

\begin{tabular}{lcccc}
\hline & \multicolumn{3}{c}{ Áreiti } & \\
\cline { 2 - 4 } & Danstónlist & Engin tónlist & Róleg tónlist & Heild \\
Kannaðist ekki við vörumerkið & 25 & 12 & 12 & 49 \\
Kannaðist við vörumerkið & 50 & 54 & 46 & 150 \\
& 75 & 66 & 58 & 199 \\
\cline { 2 - 4 } & & & \\
\hline
\end{tabular}

Búin var til breytan „skynjuð samsvörun“ úr samsvörunarspurningunum tveimur („Tónlistin í auglýsingu Blue Storm átti vel við skilaboð auglýsingarinnar“ annars vegar og „Tónlistin úr auglýsingu Blue Storm átti vel við vöruna“ hins vegar). Áreiðanleikastuðull páttarins (Cronbachs alpha) var 0,95. Úr breytunum sex (Blue Storm er orkuríkur, svalandi, örvandi, próttmikill, líflegur og spennandi) var mynduð breytan ímynd. Í báðum tilvikum var notað einfalt meðaltal viðkomandi breyta til að búa til nýja breytu.

Eins og búist var við var marktækur munur á milli hópanna tveggja sem hlustuðu á auglýsingu með tónlist pegar kom að mati peirra á skynjaðri samsvörun milli tónlistar og vörumerkis $F(2,196)=22.56, p<.01$. Til að kanna áhrifastærð (effect size) var reiknuð Eta (eta squared). Reiknuð Eta er 0.19 og var pví mikill munur á samsvöruninni milli hópanna samkvæmt skilgreiningu Cohen (1988).

\subsection{Skynjuð samsvörun og vörumerkjavitund}

Ekki kom fram munur milli hópanna á upprifjun vörumerkjaheitis pegar kannað var hvort pátttakendur myndu eftir að vörumerkið hefði verið auglýst í útvarpspættinum $\chi^{2}(2)=2.329$, $p=0.31$. Eins og sjá má á töflu 1 var athyglisvert að lítill munur reyndist á upprifjun milli hópsins par sem tónlistin (danstónlist) var samsvarandi vörumerkinu og pess hóps par sem engin tónlist var spiluð undir auglýsingunni. Tónlistin sem var ekki samsvarandi vörumerkinu (róleg tónlist) skar sig hins vegar úr með frekar litla upprifjun miðað við hina hópana tvo.

Ekki var heldur munur á milli hópanna pegar kannað var hvort pátttakendur könnuðust við að vörumerkið hefði verið auglýst $\chi 2(2)=5,025, p=0.08$. Í töflu 2 er hægt að sjá skiptingu milli hópanna pegar skoðuð var upprifjun með pessari mælingu. Tilgáta 1 um að aukin skynjuð samsvörun milli tónlistar og vörumerkis ýti undir upprifjun á vörumerkjaheiti var ekki studd.

\subsection{Skynjuð samsvörun og vörumerkjaímynd}

Úr breytunum sex (Blue Storm er orkuríkur, svalandi, örvandi, próttmikill, líflegur og spennandi) var, eins og fram hefur komið, mynduð breytan ímynd. Áreiðanleikastuðull páttarins (Cronbachs alpha) var 0,84. Ekki var marktækur munur á milli hópanna pegar skoðuð var ímynd vörumerkisins $F(2,193)=12,323, p=0.21$. Skiptingu milli hópanna má sjá í töflu 3. 
Tafla 3. Ímyndarpáttur á milli hópa

\begin{tabular}{cccc}
\hline & $\mathrm{N}$ & Meðaltal & Staðalfrávik \\
\cline { 2 - 4 } Danstónlist & 74 & 4,95 & 1,739 \\
Engin tónlist & 65 & 5,37 & 2,017 \\
Róleg tónlist & 57 & 4,75 & 2,178 \\
Heild & 196 & 5,03 & 1,973 \\
& & & \\
\hline
\end{tabular}

Ekki fékkst pví stuðningur við tilgátu 2 um að aukin skynjuð samsvörun milli tónlistar og vörumerkis hafi jákvæð tengsl við vörumerkjaímynd. Pessi niðurstaða er í andstöðu við fyrri rannsóknir (Hung, 2000, 2001; North o.fl., 2004; Lavack o.fl., 2008).

\subsection{Tónlistarsmekkur og vörumerkjaímynd}

Sökum áhrifa aldurs og kyns á tónlistarsmekk (sérstaklega danstónlist) var leiðrétt fyrir aldri og kyni pegar pessar breytur voru athugaðar.

Pegar pátttakendur í peim hópi sem hlýddu á auglýsinguna með danstónlistinni voru skoðaðir út frá almennum tónlistarsmekk kom hvorki fram fylgni við ímynd né við pær fullyrðingar sem mynda hana. Pegar pátttakendur í peim hópi sem hlýddi á auglýsinguna með rólegu tónlistinni voru skoðaðir út frá almennum tónlistarsmekk komu hins vegar fram jákvæð tengsl á milli pess að kunna að meta dægurlög og ímyndar $(\mathrm{r}(51)=0,283 ; \mathrm{p}<0,05)$. Par skýrði óháða breytan $8 \%$ af dreifingu háðu breytunnar. Tilgáta 3, um að pað ýti undir jákvæða skynjaða ímynd vörumerkis að líka vel við pá tegund tónlistar sem hljómar í auglýsingu, fékk pví nokkurn stuðning.

Hér var einnig prófað að leiðrétta fyrir skynjaða samsvörun. Ekki komu fram áhrif á ímyndarpætti pegar einungis hafði verið leiðrétt fyrir kyni og aldri en pegar jafnframt var leiðrétt fyrir samsvörun var fylgnin á mörkum marktektar. Ekki var hægt að aðskilja áhrif pess að líka við dægurlög og áhrif skynjaðrar samsvörunar á ímyndarpætti.

\section{Umræða}

Pegar könnuð voru áhrif skynjaðrar samsvörunar milli tónlistartegundar í auglýsingu og vörumerkis á vörumerkjavitund kom ekki fram marktækur munur milli hópanna og pví var tilgáta 1, um að skynjuð samsvörun hafi jákvæð áhrif á vörumerkjavitund, ekki studd. Petta er í ósamræmi við niðurstöðu North o.fl. (2004) hvað varðar að muna eftir vörumerki en í samræmi við niðurstöðu Yalch (1991) hvað varðar að kannast við vörumerki. Раð er hugsanlegt að munur hafi ekki komið fram milli danstónlistarhóps og dægurlagahóps sökum pess að í dægurlagahópi er samsvörun ekki til staðar og í danstónlistarhópi, par sem samsvörun er til staðar, er takturinn hraðari. Nýleg rannsókn benti til pess að hraðari taktur í auglýsingu geti haft truflandi áhrif á upprifjun skilaboða úr auglýsingunni (Oakes og North, 2006). Pó mátti tónlistin í pessu tilfelli ekki hægari vera til pess að standa undir nafni sem danstónlist.

Pegar könnuð voru áhrif skynjaðrar samsvörunar milli tónlistartegundar í auglýsingu og vörumerkis á vörumerkjaímynd kom heldur ekki fram munur milli hópanna og pví var tilgáta 2, um að skynjuð samsvörun hafi jákvæð áhrif á vörumerkjaímynd, ekki studd. Pessar niðurstöður eru ekki í takt við niðurstöður fyrri rannsókna á hlutverki skynjaðrar samsvörunar (Hung, 2000, 2001; North o.fl., 2004; Lavack o.fl., 2008).

Pvert á niðurstöður fyrri rannsókna, sem gáfu til kynna að samsvörun milli tónlistartegundar í auglýsingum og vörumerkis hefði jákvæð áhrif á vörumerkjaímynd, 
benda niðurstöður pessarar rannsóknar til pess að tónlistartegundin ein og sér hafi ekki pessi áhrif. Раð sem gæti skýrt pessar misvísandi niðurstöður er að í fyrri rannsóknum gæti pað hafa skekkt niðurstöðuna að pátttakendur höfðu fyrri reynslu af lögunum eða að lögin sem slík, sem notuð voru í tilraunahópunum, voru mismunandi. Frekari tilraunir par sem notuð eru fleiri frumsamin lög fyrir fleiri vörumerki og/eða pau útsett með fjölbreyttari hætti gætu varpað frekara ljósi á petta.

Einnig var skoðaður almennur smekkur pátttakenda fyrir mismunandi tegundum tónlistar. Pátttakendur í danstónlistarhópi voru skoðaðir út af fyrir sig og pað sama átti við um pátttakendur í dægurlagahópi. Hvað danstónlistarhópinn varðar var ekki að sjá að ímyndin væri jákvæðari hjá peim en öðrum. Pegar dægurlagahópurinn var skoðaður komu í ljós tengsl milli pess að kunna að meta dægurlög og ímyndar. Peir sem kunnu betur að meta dægurlög almennt höfðu jákvæðari mynd af vörumerkinu en peir sem ekki kunnu að meta dægurlög. Tilgáta 3, um pað að líka vel við pá tegund tónlistar sem hljómar í auglýsingu bæti skynjaða ímynd vörumerkisins, var pví að hluta studd. Almennur tónlistarsmekkur hafði greinilega einhver áhrif pótt pau hafi ekki mælst nógu mikil eftir öllum breytum. Áhrif almenns tónlistarsmekks héldust prátt fyrir að leiðrétt hefði verið fyrir aldri og kyni.

Niðurstöður pessarar rannsóknar eru áhugaverðar fyrir auglýsendur og aðra sem vinna að pví að byggja upp vörumerkjavirði enda fara gjarnan miklir fjármunir í að semja ný stef eða tónlist til að fylgja auglýsingum eða kaupa réttinn að lögum sem til eru fyrir. Pannig virðist ekki vera nóg að velja rétta tegund tónlistar til að spila undir tal auglýsingar fyrir vörumerki eins og fyrri rannsóknir virðast gefa til kynna. Til viðbótar pví virðist purfa að velja rétta lagið innan tónlistartegundarinnar, p.e. lag sem tekur mið af pví hvaða vörumerki er verið að auglýsa og hvað pað á að standa fyrir. Einnig benda niðurstöður pessarar rannsóknar til pess að mikilvægt sé að velja tónlist sem neytendum líkar vel við par sem sú ákvörðun hefur jákvæð áhrif á ímynd vörumerkisins.

Úrtak rannsóknarinnar samanstóð af nemendum í Háskóla Íslands. Pegar úrtak rannsóknar samanstendur einungis af nemendum fylgir pví ákveðin hætta par sem peir geta verið meðvitaðri eða forvitnari en almenningur um tilgang tilrauna (Oakes og North, 2006). Nemendur í úrtakinu voru að meirihluta nýnemar í BS námi í viðskiptafræði en einnig nýnemar í MS námi í viðskiptafræði. Pátttakendurnir póttu pví ekki almennt séð hafa mikla pekkingu á blindum tilraunum. Pátttakendunum var par að auki skipt tilviljanakennt í hópana prjá. Varðandi ytra réttmæti (external validity) rannsóknarinnar má einnig geta pess að tilraunaaðstæðurnar voru að mörgu leyti nær raunaðstæðum en gengur og gerist í svipuðum auglýsingarannsóknum par sem pátttakendur eru stundum látnir hlusta á auglýsingar og eftir hlustunina beðnir um að leysa prautaverkefni og í kjölfar pess svara spurningalista. Í pessari rannsókn var reynt að líkja eftir útvarpspætti og pátttakendum talin trú um að hlutverk peirra væri að meta útvarpspáttinn. Auglýsingin sem um ræðir var par ein af premur auglýsingum í pættinum en pátturinn var sex mínútna langur.

Meiri áhrif hefði ef til vill mátt fá fram með pví að bera saman enn ólíkari tegundir tónlistar en dægurlög og danstónlist. Bæði lögin (dægurlagið og danslagið) voru hefðbundin (mainstream) popplög prátt fyrir að annað hafi verið ballaða en hitt danslag. Petta er kannski sérstaklega mikilvægt ef leitast er við að fá fram mun í jafn einsleitu úrtaki og pessi tilraun studdist við. Pátttakendur voru langflestir ungir Íslendingar. Meiri áhrif hefði ef til vill verið hægt að fá fram með pví að bera saman popptónlist og jass eða popptónlist og kántrítónlist sem er ekki eins vinsæl meðal ungra Íslendinga.

Prátt fyrir ofangreinda varnagla veita niðurstöður rannsóknarinnar vísbendingar um áhrif tónlistar í auglýsingum. 


\section{Heimildir}

Aaker, D. A. (1991). Managing brand equity. New York: Free Press.

Allan, D. (2006). Effects of popular music in advertising on attention and memory. Journal of Advertising Research, 46(4), 434-444.

Attila, S. og Cakir, B. (2010). Energy-drink consumption in college students and associated factors. Nutrition Journal, Feb. 1-7.

Cohen, J. (1988). Statistical power analysis for the behavioural sciences. Hillsdale, NJ.

Farquhar, P. (1989). Managing brand equity. Journal of advertising research, 30( 4), RC7-RC12.

Gorn, G. J. (1982). The effects of music in advertising on choice behaviour: A classical conditioning approach. Journal of Marketing, 46(1), 94-101.

Hung, K. (2000). Narrative music in congruent and incongruent TV advertising. Journal of Advertising, 29(1), 25-34.

Hung, K. (2001). Framing meaning perceptions with music: The case of teaser ads. Journal of Advertising, 30(3), 39-49.

Kellaris, J. J. og Cox, A. D. (1989). The effects of background music in advertising: A reassessment. Journal of Consumer Research, 16(1), 113-118.

Kellaris, J. J., Cox, A. og Cox, D. (1993). The effect of background music on ad processing - A contingency explanation. Journal of Marketing, 57(4), 114-125.

Keller, K. L. (1993). Conceptualizing, measuring, and managing customer-based brand equity. Journal of Marketing, 57(1), 1-22.

Keller, L. K., Apéria, T. og Georgson, M. (2008). Strategic Brand Management - A European Perspective. Pearson Education Limited.

Keller, K. L. og Lehmann, D. R. (2006). Brands and branding: Research findings and future priorities. Marketing Science, 25(6), 740-761.

Lavak, A.M., Thakor, M.V. og Bottausci, I. (2008). Music-brand congruency in high- and lowcognition radio advertising. International Journal of Advertising, 27(4), 549-568.

MacInnis, D. J og C. W. Park. (1991). The differential role of characteristics of music on highand low-involvement consumers' processing of ads. Journal of Consumer Research, 18, (2), 161-73.

North, A. C., Hargreaves, D. J., MacKenzie, L. C. og Law, R. C. (2004). The effects of musical and voice 'fit' on responses to advertisements. Journal of Applied Social Psychology, 34(8), 1675-1708.

North, A. C., Shilcock, A. og Hargreaves, D. J. (2003). The effect of musical style on restaurant customers' spending. Environment and Behaviour, 35(5), 712-718.

Oakes, S. (2007). Evaluating empirical research into music in advertising: A congruity perspective. Journal of Advertising Research, 47 (1), 38-50.

Oakes, S. og North, A. C. (2006). The impact of background musical tempo and timbre congruity upon ad content recall and affective response. Applied Cognitive Psychology, 20(4), 505-520.

Simpkins, J. D. og Smith, J. A. (1974). Effects of music on source evaluations. Journal of Broadcasting, 18(3), 361-367.

Tom, G. (1990). Marketing with music. The Journal of Consumer Marketing, 7(2), 49-53.

Wilson, S. (2003). The effect of music on perceived atmosphere and purchase intentions in a restaurant. Psychology of Music, 31(1), 93-112.

Yalch, R.F. (1991). Memory in a jingle jungle: Music as a mnemonic device in communicating advertising slogans. Journal of Applies Psychology, 76(2), 268-275. 
14 Tímarit um viðskipti og efnahagsmál

Yoo, B., Donthu, N., og Lee, S. (2000). An examination of selected marketing mix elements and brand equity. Journal of the Academy of Marketing Science, 28(2), 195-211. 